\title{
PENGARUH BELANJA PENDIDIKAN DAN BELANJA KESEHATAN TERHADAP TINGKAT KEMISKINAN MELALUI TINGKAT PENDIDIKAN DAN DERAJAT KESEHATAN DI KOTA JAMBI
}

\section{Eri Nofriza}

Universitas Islam Negeri Sulthan Thaha Saifuddin, Jambi, Indonesia

Email: erinofriza@uinjambi.ac.id

\begin{tabular}{l}
\hline INFO ARTIKEL \\
\hline Diterima \\
5 April 2021 \\
Direvisi \\
10 April 2021 \\
Disetujui \\
15 April 2021 \\
\hline
\end{tabular}

\section{Keywords:}

level of education; degree of health; education spending; health spending; level to level

\begin{abstract}
This study aims to the influence of education spending and health spending is more than human resources in Jambi City. The influence of education spending and education level health spending in Jambi City. Influence the influence of human resources on the level of education in Jambi City. The results of the study can be concluded that education spending is very good and positive in degree education, as well as sugarcane health spending and positive towards degree health. The direct effect of education spending on education degrees was 54 percent and the direct influence of health spending on health degrees was 76.7 percent. For structural equation III shows that partially only variable health degrees that affect poverty in Jambi City. After the Trimming model, the results showed that health degrees had a significant and positive effect on poverty. The direct effect of health degrees on poverty was 74.2 percent.
\end{abstract}

\begin{abstract}
ABSTRAK
Penelitian ini bertujuan untuk menganalisis pengaruh belanja pendidikan dan belanja kesehatan terhadap kualitas sumber daya manusia di kota Jambi. menganalisis pengaruh belanja pendidikan dan belanja kesehatan terhadap tingkat kemiskinan di kota Jambi. menganalisis pengaruh kualitas sumber daya manusia terhadap tingkat kemiskinan di kota Jambi. Berdasarkan hasil penelitian dapat disimpulkan persamaan struktural I menunjukkan bahwa belanja pendidikan berpengaruh signifikan dan positif terhadap derajat pendidikan, begitu juga belanja kesehatan berpengaruh signifikan dan positif terhadap derajat kesehatan. Pengaruh langsung belanja pendidikan terhadap derajat pendidikan sebesar 54 persen dan pengaruh langsung belanja kesehatan terhadap
\end{abstract}




\section{Kata kunci:}

tingkat pendidikan; derajat kesehatan; belanja

pendidikan;

kesehatan;

kemiskinan derajat kesehatan sebesar 76,7 persen. Untuk persamaan struktural III menunjukkan bahwa secara parsial hanya variabel derajat kesehatan yang berpengaruh terhadap kemiskinan di kota Jambi. Setelah dilakukan model Trimming, hasil menunjukkan bahwa derajat kesehatan berpengaruh signifikan dan positif terhadap kemiskinan. Pengaruh langsung derajat kesehatan terhadap kemiskinan sebesar 74,2 persen.

\section{Pendahuluan}

Kemiskinan merupakan suatu keadaan yang sering dihubungkan dengan kebutuhan, kesulitan dan kekurangan di berbagai keadaan hidup (Jasasila, 2020). Menurut Rintuh (2003), kemiskinan dapat diartikan sebagai ketidakmampuan seseorang dalam memenuhi kebutuhan konsumsi dasar dan meningkatkan kebutuhan konsumsi dasar dan kualitas hidupnya. Ada dua macam ukuran kemiskinan yaitu kemiskinan absolut dan kemiskinan relatif. Kemiskinan absolut adalah ketidakmampuan seseorang melampaui garis kemiskinan yang ditetapkan. Sedangkan kemiskinan relative berkaitan dengan perbedaan tingkat pendapatan suatu golongan dibandingkan dengan golongan lainnya (Harlik et al., 2013).

Berdasarkan ciri-ciri dari kemiskinan menurut (Romi \& Umiyati, 2018) adalah penduduk yang berpendapatan rendah, buta huruf, angka harapan hidup yang rendah dan ketimpangan sex serta buruknya lingkungan hidup. World Bank mengatakan faktorfaktor terjadinya kemiskinan adalah akibat dari kurangnya pendapatan dan aset untuk memenuhi kebutuhan dasar seperti perumahan, makanan dan derajat kesehatan serta tingkat pendidikan yang diperoleh. Kemudian, kemiskinan juga dapat dikaitkan dengan sempitnya lapangan pekerjaan dan pada umumnya penduduk yang dikategorikan miskin karena belum memiliki atau sedang mencari pekerjaan (pengangguran), serta pendidikan dan kesehatan yang umumnya tidak memadai (Faturahman, 2019). Mengatasi permasalahan kemiskinan selalu berkaitan dengan masalah-masalah pendidikan, pengangguran, kesehatan dan permasalahan lain yang secara eksplisit terkait dengan masalah kemiskinan. Dengan maksud lain, pendekatannya harus dilakukan lintas sektor, lintas pelaku secara terpadu dan terkoordinasi serta terintegrasi (Putriani et al., 2018).

Permasalahan kemiskinan menjadi permasalahan bagi pemerintah daerah di seluruh wilayah di Indonesia termasuk bagi pemerintah daerah provinsi Jambi. Kondisi kemiskinan tentunya berbeda-beda pada setiap wilayah karena kondisi faktor-faktor yang memengaruhi kemiskinan masing-masing wilayah juga berbeda.

Berdasarkan information tingkat kemiskinan kabupaten/kota di provinsi Jambi selama tahun 2003 hingga tahun 2019, dapat tergambarkan bahwa tingkat kemiskinan pada kabupaten/kota di provinsi Jambi masih cenderung mengalami fluktuasi untuk rata-rata tingkat kemiskinan di provinsi Jambi selama tahun 2003 hingga tahun 2019 sebesar 9,42 persen, seharusnya pemerintah daerah masing-masing kabupaten/kota di provinsi Jambi mampu untuk mengatasi kemiskinan di daerahnya masing-masing 
(Hujaipah et al., 2020). Rata-rata tingkat kemiskinan tertinggi terjadi di kabupaten Tanjung Jabung Timur dan Tanjung Jabung Barat dengan tingkat kemiskinan yang sangat tinggi dibandingkan kabupaten/kota lainnya yaitu sebesar 12,65 persen dan 12,62 persen setiap tahunnya, sementara rata-rata tingkat kemiskinan terendah terjadi pada kota Sungai penuh yaitu hanya 3,25 persen setiap tahunnya (Daulay et al., 2016). Sedangkan Kota Jambi yang merupakan pusat kota dan banyak kesempatan kerja namun tingkat kemiskinannya masih tinggi yaitu sebesar 8,02 persen.

Masih tingginya tingkat kemiskinan di kota Jambi tidak terlepas dari strategi pembangunan yang diterapkan. Strategi pembangunan dilaksanakan dengan mengutamakan pertumbuhan ekonomi yang tinggi sebagai jalan keluar untuk mengatasi berbagai persoalan sosial dan politik, akan tetapi pengalaman menunjukkan bahwa efek menetes kebawah yang diharapkan tidak berjalan sempurna, pertumbuhan ekonomi yang dicapai belum diikuti penurunan jumlah kemiskinan sehingga tingkat kemiskinan juga masih tinggi (Hardiani \& Junaidi, 2011).

Lanjouw (2008) menyatakan pembangunan manusia di Indonesia adalah identik dengan pengurangan kemiskinan (Putro et al., 2018). Investasi di bidang pendidikan oleh pemerintah dalam bentuk belanja pendidikan dan kesehatan oleh pemerintah dalam bentuk belanja kesehatan akan lebih berarti bagi penduduk miskin dibandingkan penduduk tidak miskin, karena bagi penduduk miskin aset utama adalah tenaga kasar mereka. Adanya fasilitas pendidikan dan kesehatan murah akan sangat membantu untuk meningkatkan produktivitas dan pada gilirannya meningkatkan pendapatan. Keterbelakangan SDM salah satunya diselesaikan dengan peningkatan kuantitas dan kualitas tingkat pendidikan. Semakin tinggi kualitas pendidikan dan semakin banyak lulusan pendidikan menengah dan tinggi, maka semakin mampu manusia memberikan kontribusi bagi pembangunan. Semakin tinggi tingkat pendidikan dan derajat kesehatan, cenderung semakin besar peluang masyarakat atau penduduk dalam mencari pekerjaan dan menciptakan lapangan pekerjaan, sehingga dapat mengurangi jumlah kemiskinan (Jalaluddin et al., 2018). Tingkat pendidikan dilihat dari persentase penduduk umur 20 tahun keatas yang tamat pendidikan SMA ke atas, sementara derajat kesehatan dilihat dari Angka Harapan Hidup (AHH) (Rismawati, 2018).

Tingkat pendidikan yang ditunjukkan oleh persentase penduduk umur 20 tahun keatas yang tamat pendidikan SMA ke atas sebagai indikatornya juga berpengaruh terhadap jumlah kemiskinan karena tingkat pendidikan merupakan salah satu komponen yang tekankan dalam penyebab lingkaran setan kemiskinan. Salah satu cara untuk mengatasinya adalah melalui pendidikan dasar wajib oleh pemerintah diterjemahkan dalam program wajib belajar dua belas tahun.

Sama halnya dengan tingkat pendidikan, derajat kesehatan berpengaruh terhadap tingkat kemiskinan karena perbaikan derajat kesehatan pada dasarnya merupakan suatu investasi sumber daya manusia untuk mencapai masyarakat yang sejahtera (welfaresociety) (Winarti \& Purwanti, 2014). Derajat kesehatan masyarakat yang ditunjukkan oleh AHH sebagai indikatornya akan sangat berpengaruh terhadap tingkat kesejahteraan masyarakat dan memiliki keterkaitan yang erat dengan pengangguran dan 
kemiskinan (Putriani et al., 2018). Sementara itu, tingkat kemiskinan akan terkait dengan tingkat kesejahteraan. Oleh karena itu, kesehatan merupakan faktor utama dalam upaya peningkatan kesejahteraan masyarakat, maka kesehatan selalu menjadi perhatian utama pemerintah sebagai penyelenggara pelayanan publik. Pemerintah harus dapat menjamin hak masyarakat untuk sehat (right for wellbeing) dengan memberikan pelayanan kesehatan secara adil, merata, memadai, terjangkau dan berkualitas (Pake et al., 2018).

Dalam kurun waktu tahun 2003 sampai tahun 2019, belanja pendidikan dan belanja kesehatan yang direalisasikan oleh pemerintah kota Jambi setiap tahunnya mengalami peningkatan. Hal tersebut diiringi dengan peningkatan tingkat pendidikan dan derajat kesehatan, namun pengentasan kemiskinan masih belum dapat terwujud (Permana et al., 2020). Berdasarkan fakta-fakta yang telah dikemukakan maka penulis tertarik untuk melakukan penelitian tentang kemiskinan yaitu dengan judul "Pengaruh Belanja Pendidikan dan Belanja Kesehatan terhadap Tingkat Kemiskinan Melalui Tingkat Pendidikan dan Derajat Kesehatan di kota Jambi”.

\section{Metode Penelitian}

Metode analisis yang digunakan dalam penelitian ini adalah analisis deskriptif kualitatif dan kuantitatif. Analisis deskriptif kualitatif digunakan untuk mendeskripsikan fenomena-fenomena yang berkaitan dengan permasalahan yang berkaitan dengan masalah yang diteliti. Sedangkan analisis kuantitatif digunakan untuk menganalisis informasi kuantitatif (information yang dapat diukur, diuji dan diinformasikan dalam bentuk persamaan, tabel, dan sebagainya).

\section{Hasil dan Pembahasan}

1. Pengaruh Belanja Pendidikan dan Belanja Kesehatan Terhadap Tingkat Pendidikan dan Derajat Kesehatan di Kota Jambi

Berikut ini merupakan ringkasan koefisien jalur hasil olahan data regresi. Berdasarkan tabel 1 sebagai berikut:

\section{Tabel 1}

Hasil Persamaan Struktural I

\begin{tabular}{lllll}
\hline Variabel & & Coefficients & Prob t & $\mathbf{R}^{2}$ \\
\cline { 1 - 3 } Dari & $\mathrm{Ke}$ & (Beta) & & \\
\hline $\mathbf{X}_{\mathbf{1}}$ & $\mathrm{Y}_{1}$ & 0,735 & 0,001 & 0,540 \\
\hline $\mathbf{X}_{\mathbf{2}}$ & $\mathrm{Y}_{2}$ & 0,876 & 0,000 & 0,767 \\
\hline
\end{tabular}

Sumber: SPSS, 22 Data Diolah, 2021

Variabel belanja pendidikan $\left(\mathrm{X}_{1}\right)$ terhadap tingkat pendidikan ( $\left.\mathrm{Y}_{1}\right)$ nilai probabilita t-nya adalah 0,001 lebih kecil dari 0,05 dan variabel belanja kesehatan $\left(\mathrm{X}_{2}\right)$ terhadap derajat kesehatan $\left(\mathrm{Y}_{2}\right)$ terlihat nilai probabilitas t-nya sebesar 0,000 lebih kecil dari 0,05. Sedangkan nilai residu $\varepsilon i_{1}=1-0,540=0,460$ dan $\varepsilon i_{2}=1-0,767=0,233$ sehingga diperoleh persamaan struktural I:

$$
\mathrm{Y}_{1}=\rho \mathrm{y}_{1} \mathrm{x}_{1} \mathrm{X}_{1}+\rho \mathrm{y}_{1} \varepsilon \mathrm{i}_{1} \longrightarrow \mathrm{Y}_{1}=0,735 \mathrm{X}_{1}+0,460 \varepsilon \mathrm{i}_{1}
$$




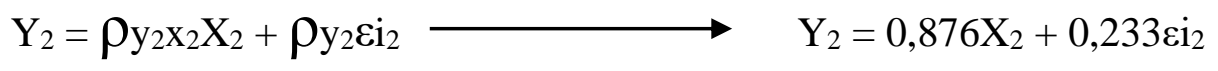

Diagram jalurnya digambarkan pada gambar 2 berikut:
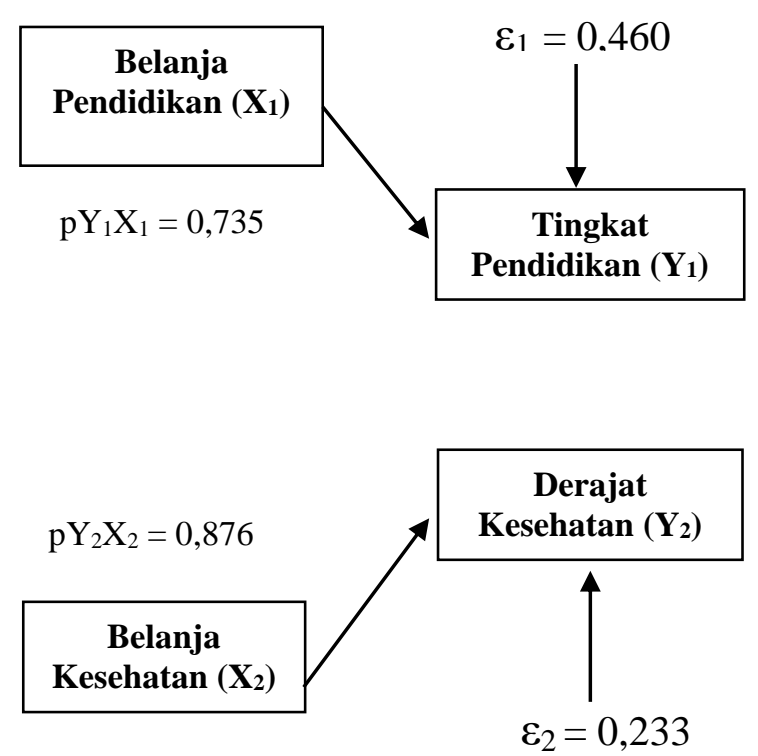

Gambar 2

Diagram Hasil Jalur Persamaan Struktural I

Dari gambar 2 dapat dihitung pengaruh langsung variabel eksogen terhadap variabel endogen, sementara pengaruh tidak langsung dan pengaruh total tidak dapat dilakukan karena setiap persamaan hanya terdiri dari 1 variabel bebas. Untuk mengetahui besarnya pengaruh variabel eksogen terhadap variabel endogen secara proporsional adalah sebagai berikut:

1. Pengaruh belanja pendidikan $\left(\mathrm{X}_{1}\right)$ terhadap tingkat pendidikan $\left(\mathrm{Y}_{1}\right)$

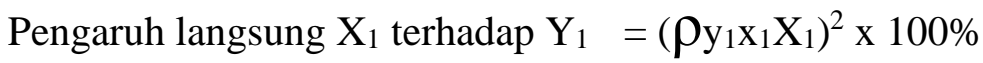

$$
\begin{aligned}
& =(0,, 735)^{2} \times 100 \% \\
& =54 \%
\end{aligned}
$$

2. Pengaruh belanja kesehatan $\left(\mathrm{X}_{2}\right)$ terhadap derajat kesehatan $\left(\mathrm{Y}_{2}\right)$

Pengaruh langsung $\mathrm{X}_{2}$ terhadap $\mathrm{Y}_{2}=\left(\mathrm{y}_{2} \mathrm{x}_{2} \mathrm{X}_{2}\right)^{2} \times 100 \%$

$$
\begin{aligned}
& =(0,876)^{2} \times 100 \% \\
& =76,7 \%
\end{aligned}
$$

Pengaruh langsung variabel belanja pendidikan $\left(\mathrm{X}_{1}\right)$ terhadap Tingkat Pendidikan ( $\left.\mathrm{Y}_{1}\right)$ dapat terlihat pada tabel 2 berikut: 
Tabel 2

Pengaruh Langsung Variabel Belanja Pendidikan $\left(\mathrm{X}_{1}\right)$ Terhadap Tingkat Pendidikan $\left(\mathbf{Y}_{1}\right)$

\begin{tabular}{lcc}
\hline Pengaruh & Pengaruh Kausal & Pengaruh \\
\hline Variabel & Langsung & Total \\
\hline & $(\%)$ & $(\%)$ \\
\hline $\mathrm{X}_{1} \rightarrow \mathrm{Y}_{1}$ & 54,0 & 54,0 \\
\hline Pengaruh Variabel $\mathrm{X}_{1}$ terhadap $\mathrm{Y}_{1}=\mathrm{R}^{2}$ & & 54,0 \\
\hline Pengaruh Variabel Luar & & 46,0 \\
\hline TOTAL & & 100,0 \\
\hline
\end{tabular}

Sumber: SPSS, 22 Data Diolah, 2021

Berdasarkan tabel 2 menunjukkan kekuatan belanja pendidikan $\left(\mathrm{X}_{1}\right)$ yang secara langsung menentukan perubahan-perubahan tingkat pendidikan ( $\left.\mathrm{Y}_{1}\right)$ sebesar 54 persen.

Pengaruh langsung variabel belanja kesehatan $\left(\mathrm{X}_{2}\right)$ terhadap derajat kesehatan $\left(\mathrm{Y}_{2}\right)$ dapat terlihat pada tabel 3 berikut:

Tabel 3

Pengaruh Langsung Belanja Kesehatan $\left(\mathbf{X}_{2}\right)$ Terhadap Derajat Kesehatan $\left(\mathbf{Y}_{2}\right)$

\begin{tabular}{lcc}
$\begin{array}{l}\text { Pengaruh } \\
\text { Variabel }\end{array}$ & $\begin{array}{c}\text { Pengaruh Kausal } \\
\text { Langsung } \\
(\boldsymbol{\%})\end{array}$ & $\begin{array}{c}\text { Pengaruh } \\
\text { Total } \\
(\boldsymbol{\%})\end{array}$ \\
\hline $\mathrm{X}_{2} \rightarrow \mathrm{Y}_{2}$ & 76,7 & 76,7 \\
\hline Pengaruh Variabel $\mathrm{X}_{2}$ terhadap $\mathrm{Y}_{2}=\mathrm{R}^{2}$ & & 76,7 \\
\hline Pengaruh Variabel Luar & & 23,3 \\
\hline TOTAL & & 100,0 \\
\hline
\end{tabular}

Sumber: SPSS, 22 Data Diolah, 2021

Berdasarkan tabel 3 menunjukkan kekuatan belanja kesehatan $\left(\mathrm{X}_{2}\right)$ yang secara langsung menentukan perubahan-perubahan derajat kesehatan $\left(\mathrm{Y}_{2}\right)$ sebesar 76,7 persen.

2. Pengaruh Belanja pendidikan dan Belanja kesehatan terhadap Tingkat Kemiskinan di kota Jambi

Menganalisis pengaruh langsung variabel belanja pendidikan terhadap tingkat kemiskinan dan pengaruh tidak langsung melalui belanja kesehatan serta pengaruh langsung belanja kesehatan terhadap tingkat kemiskinan dan pengaruh tidak langsung melalui belanja pendidikan.

Persamaan Struktural II: $\quad Y_{3}=\rho y_{3} x_{1} X_{1}+\rho y_{3} x_{2} X_{2}+\rho y_{3} \varepsilon i_{3}$. 


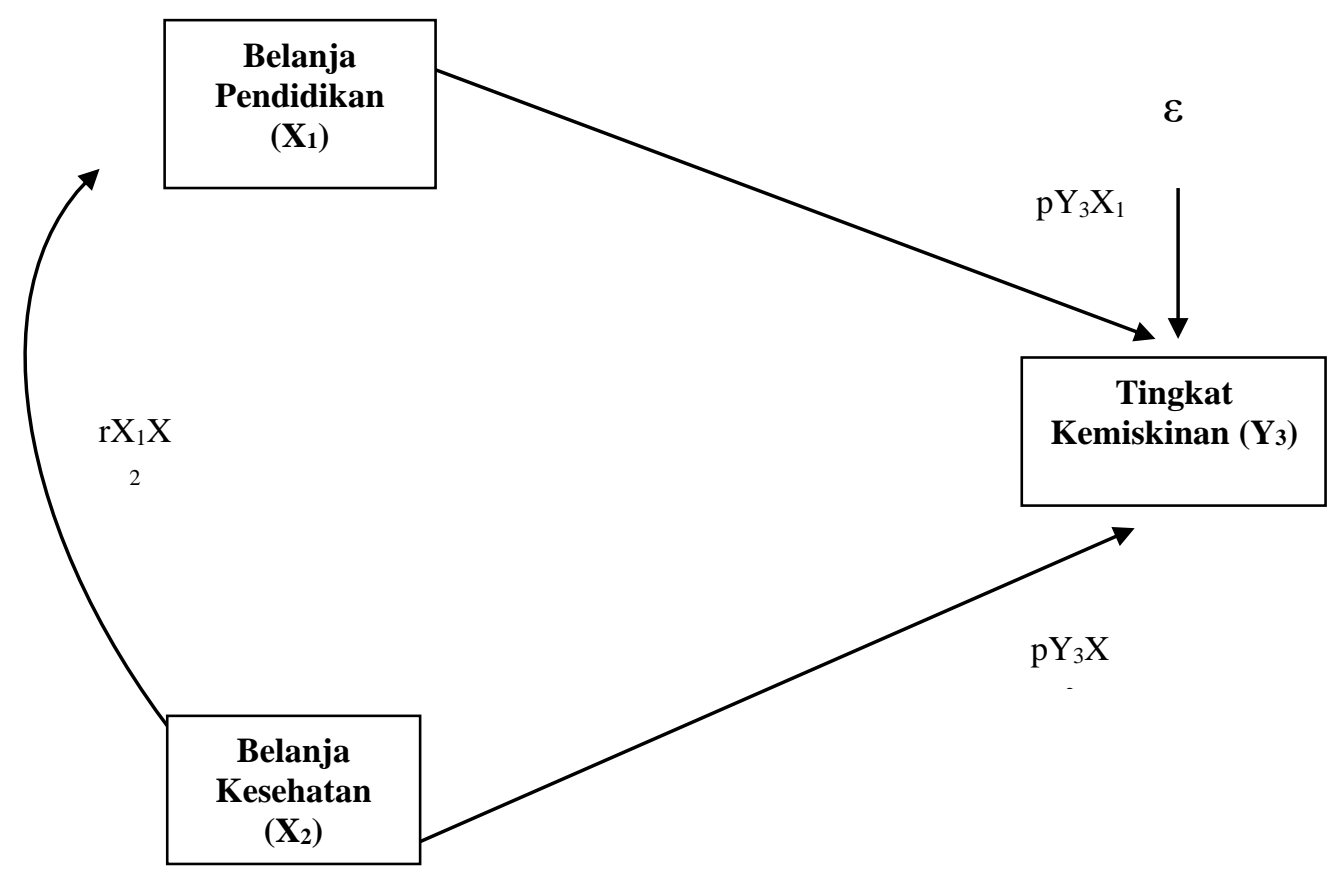

\section{Gambar 3}

Diagram Jalur Model Persamaan Struktural II

Untuk mencari hubungan langsung dan tidak langsung atau pengaruh variabelvariabel penelitian, terlebih dahulu dihitung matriks korelasi dari masing-masing variable bebas. Berikut adalah hasil perhitungan koefisien korelasi dengan menggunakan SPSS 20:

Tabel 4

Hasil Uji Korelasi Persamaan Struktural II

\begin{tabular}{|c|c|c|c|}
\hline \multicolumn{2}{|c|}{ Correlations } & $\mathbf{X 1}$ & $\mathbf{X} 2$ \\
\hline \multirow{3}{*}{$\mathrm{X} 1$} & Pearson Correlation & 1 & ,995* \\
\hline & Sig. (2-tailed) & &, 000 \\
\hline & $\mathrm{N}$ & 17 & 17 \\
\hline \multirow{3}{*}{$\mathrm{X} 2$} & Pearson Correlation &, $995^{* *}$ & 1 \\
\hline & Sig. (2-tailed) &, 000 & \\
\hline & $\mathrm{N}$ & 17 & 17 \\
\hline
\end{tabular}

Sumber: SPSS, 22 Data Diolah, 2021

Berdasarkan hasil pengujian pada tabel 4 maka dapat diketahui bahwa nilai korelasi antara belanja pendidikan $\left(\mathrm{X}_{1}\right)$ dan belanja kesehatan $\left(\mathrm{X}_{2}\right)$ mempunyai hubungan yang sangat kuat dengan nilai koefisien korelasi sebesar 0,995 dengan arah positif dan signifikan $(0,000<0,05)$. Dari penjelasan tersebut dapat diketahui kedua variabel mempunyai hubungan yang positif, juga terdapat hubungan yang sangat kuat 
dan signifikan. Selanjutnya pada bagian ini dilakukan pendugaan koefisien jalur, berikut ini merupakan ringkasan koefisien jalur hasil olahan data regresi. Berdasarkan tabel 5 dibawah ini:

Tabel 5

\begin{tabular}{|c|c|c|c|c|c|}
\hline \multicolumn{6}{|c|}{ Koefisien Jalur Persamaan struktural II } \\
\hline \multicolumn{2}{|c|}{ Variabel } & \multirow{2}{*}{$\begin{array}{c}\text { Coefficients } \\
\text { (Beta) }\end{array}$} & \multirow{2}{*}{ Prob $t$} & \multirow{2}{*}{ F sig } & \multirow[t]{2}{*}{$\mathbf{R}^{2}$} \\
\hline Dari & Ke & & & & \\
\hline $\mathbf{X}_{1}$ & \multirow[t]{2}{*}{$\mathrm{Y}_{3}$} & 1,542 & 0,406 & \multirow[t]{2}{*}{0,003} & \multirow[t]{2}{*}{0,508} \\
\hline $\mathbf{X}_{2}$ & & $-0,795$ & $-0,665$ & & \\
\hline
\end{tabular}

Sumber: SPSS, 22 Data Diolah, 2021

Berdasarkan tabel 5 diatas dapat diketahui bahwa nilai $\mathrm{R}^{2} 0,508$, nilai tersebut menunjukkan bahwa variabel belanja pendidikan $\left(\mathrm{X}_{1}\right)$ dan belanja kesehatan $\left(\mathrm{X}_{2}\right)$ mampu menjelaskan pengaruhnya terhadap variabel kemiskinan $\left(\mathrm{Y}_{3}\right)$ sebesar 50,8\%. Sedangkan 49,2\% dipengaruhi oleh variabel lain diluar model.

Berdasarkan hasil uji $\mathrm{F}$ diketahui nilai signifikansi $\mathrm{F}$ statistik sebesar 0,003 lebih kecil dari 0,05 sehingga dapat dikatakan variabel belanja pendidikan $\left(\mathrm{X}_{1}\right)$ dan belanja kesehatan $\left(\mathrm{X}_{2}\right)$ secara simultan berpengaruh terhadap variabel kemiskinan $\left(\mathrm{Y}_{3}\right)$. Selanjutnya pengujian secara individual ( $\left.\mathrm{Uji} \mathrm{t}\right)$ diketahui nilai probabilitas $\mathrm{t}$ statistik variabel belanja pendidikan $\left(\mathrm{X}_{1}\right)$ dan belanja kesehatan $\left(\mathrm{X}_{2}\right)$ masing-masing sebesar 0,406 untuk variabel belanja pendidikan $\left(\mathrm{X}_{1}\right)$ dan 0,665 untuk variabel belanja kesehatan $\left(\mathrm{X}_{2}\right)$, seluruh variabel bebas lebih besar dari 0,05. Hal ini berarti koefisien jalur belanja pendidikan $\left(\mathrm{X}_{1}\right)$ dan belanja kesehatan $\left(\mathrm{X}_{2}\right)$ tidak berpengaruh signifikan terhadap kemiskinan ( $\left.\mathrm{Y}_{3}\right)$, maka model persamaan struktural II tidak dapat dilakukan ke analisis selanjutnya dalam bentuk path analysis.

Berdasarkan pendapat dari (Mudayana \& Suryoko, 2016) jika terdapat variabel endogen yang diuji secara parsial ternyata terdapat variabel yang tidak berpengaruh signifikan, maka alternatifnya menggunakan model trimming. Model trimming yaitu suatu model yang dapat digunakan dengan tujuan untuk memperbaiki suatu model struktur analisis jalur dengan cara mengeluarkan variabel eksogen yang koefisien jalurnya tidak signifikan. Walaupun terdapat satu, dua, atau lebih variabel yang tidak berpengaruh signifikan, peneliti perlu memperbaiki model struktur analisis jalur yang telah dihipotesiskan. Akan tetapi apabila seluruh variabel bebas berpengaruh maka uji model trimming tidak perlu dilakukan.

3. Pengaruh Tingkat Pendidikan dan Derajat Kesehatan terhadap Kemiskinan di kota Jambi

Pembahasan ketiga ini akan menganalisis pengaruh langsung variabel tingkat pendidikan terhadap tingkat kemiskinan dan pengaruh tidak langsung melalui derajat kesehatan serta pengaruh langsung derajat kesehatan terhadap tingkat kemiskinan dan pengaruh tidak langsung melalui tingkat pendidikan

Persamaan Struktural III: $Y_{3}=\rho y_{3} y_{1} Y_{1}+\rho y_{3} y_{2} Y_{2}+\rho y_{3} \varepsilon i_{4}$ 


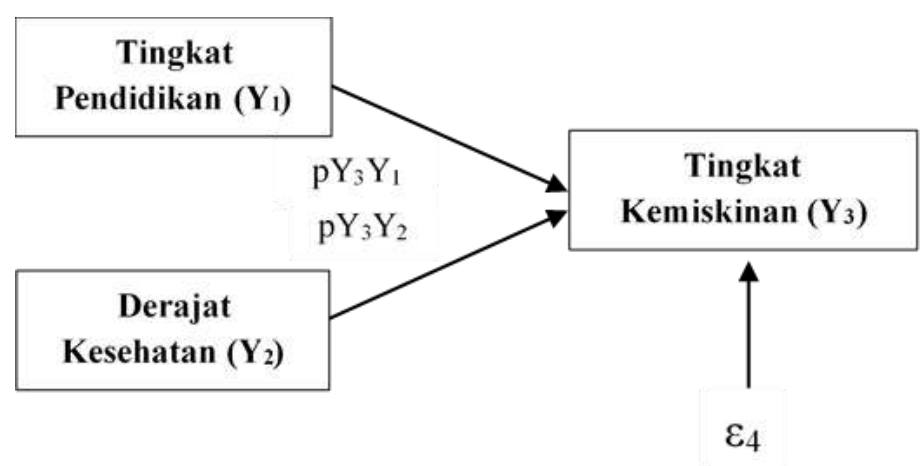

Gambar 5

Diagram Jalur Model Persamaan Struktural III

Untuk mencari hubungan langsung dan tidak langsung atau pengaruh variabelvariabel penelitian, terlebih dahulu dihitung matriks korelasi dari masing-masing variable bebas. Berikut adalah hasil perhitungan koefisien korelasi dengan menggunakan SPSS 20:

Tabel 6

Hasil Uji Korelasi Persamaan Struktural III

\begin{tabular}{|c|c|c|c|}
\hline \multicolumn{4}{|c|}{ Correlations } \\
\hline & & Y1 & Y2 \\
\hline \multirow{3}{*}{ Y1 } & Pearson Correlation & 1 & $849^{* * *}$ \\
\hline & Sig. (2-tailed) & & ,000 \\
\hline & $\mathrm{N}$ & 17 & 17 \\
\hline \multirow{3}{*}{ Y2 } & Pearson Correlation & $849^{* *}$ & 1 \\
\hline & Sig. (2-tailed) &, 000 & \\
\hline & $\mathrm{N}$ & 17 & 17 \\
\hline
\end{tabular}

Berdasarkan hasil pengujian pada tabel 6 maka dapat diketahui bahwa nilai korelasi antara tingkat pendidikan $\left(\mathrm{Y}_{1}\right)$ dengan derajat kesehatan $\left(\mathrm{Y}_{2}\right)$ mempunyai hubungan yang sangat kuat dengan nilai koefisien korelasi sebesar 0,849 dengan arah positif dan signifikan $(0,000<0,05)$. Dari penjelasan tersebut dapat diketahui kedua variabel mempunyai hubungan yang positif, juga terdapat hubungan yang sangat kuat dan signifikan.

Pada bagian selanjutnya yaitu dilakukan pendugaan koefisien jalur, berikut ini merupakan ringkasan koefisien jalur hasil olahan data regresi. Berdasarkan tabel 7 dibawah ini:

Tabel 7

Koefisien Jalur Persamaan Struktural III

\begin{tabular}{cccccc}
\hline \multicolumn{2}{c}{ Variabel } & \multicolumn{1}{c}{ Coefficients } & Prob t & F sig & $\mathbf{R}^{\mathbf{2}}$ \\
\cline { 1 - 4 } Dari & Ke & (Beta) & & & \\
\cline { 1 - 4 } $\mathbf{Y}_{\mathbf{1}}$ & $\mathrm{Y}_{3}$ & 0,087 & 0,741 & 0,000 & 0,744 \\
\cline { 1 - 1 } & & 0,788 & 0,008 & & \\
\hline
\end{tabular}

Sumber: SPSS, 22 Data Diolah, 2021 
Berdasarkan tabel 7 diatas dapat diketahui bahwa nilai $\mathrm{R}^{2} 0,744$, nilai tersebut menunjukkan bahwa variabel tingkat pendidikan $\left(\mathrm{Y}_{1}\right)$ dengan derajat kesehatan $\left(\mathrm{Y}_{2}\right)$ mampu menjelaskan pengaruhnya terhadap variabel kemiskinan $\left(\mathrm{Y}_{3}\right)$ sebesar 74,4 persen. Sisanya sebesar 25,6 persen dipengaruhi oleh variabel lain di luar model.

Berdasarkan hasil Uji F dapat diketahui nilai signifikansi F sebesar 0,000 dan lebih kecil dari 0,05, sehingga dapat dikatakan variabel tingkat pendidikan ( $\left.\mathrm{Y}_{1}\right)$ dengan derajat kesehatan $\left(\mathrm{Y}_{2}\right)$ secara simultan berpengaruh terhadap variabel kemiskinan $\left(\mathrm{Y}_{3}\right)$. Selanjutnya pengujian secara individual (Uji $\mathrm{t}$ ) diketahui nilai signifikansi probabilita $t$ statistik variabel tingkat pendidikan $\left(\mathrm{Y}_{1}\right)$ dengan derajat kesehatan $\left(\mathrm{Y}_{2}\right)$ masing-masing sebesar 0,741 untuk variabel tingkat pendidikan $\left(\mathrm{Y}_{1}\right)$ lebih besar dari 0,05 dan 0,008 untuk variabel derajat kesehatan $\left(\mathrm{Y}_{2}\right)$ lebih kecil dari 0,05 , hal ini berarti koefisien jalur derajat kesehatan $\left(\mathrm{Y}_{2}\right)$ berpengaruh signifikan terhadap kemiskinan $\left(\mathrm{Y}_{3}\right)$, maka model persamaan struktural III perlu diperbaiki melalui model Trimming. Atas dasar proposisi yang telah diperbaiki ini, diagram jalur menjadi:

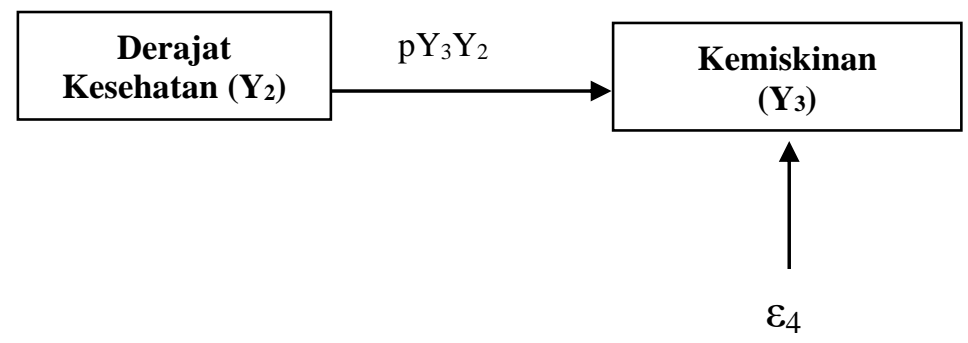

\section{Gambar 6 \\ Diagram Jalur Model Persamaan Struktural III Metode Trimming}

Dengan persamaan struktural berubah menjadi: $\mathrm{Y}_{3}=\rho \mathrm{y}_{3} \mathrm{y}_{2} \mathrm{Y}_{2}+\rho \mathrm{y}_{3} \varepsilon \mathrm{i}_{4}$

Berdasarkan gambar 6 bahwa diagram jalur telah mengurangi satu variabel eksogen dan hanya bersisa satu variabel eksogen yaitu derajat kesehatan $\left(\mathrm{Y}_{2}\right)$, dengan dihapusnya satu variabel eksogen dari diagram jalur sehingga besarnya koefisien jalur akan berubah. Oleh karena itu perhitungan harus diulang kembali. Hasil perhitungan regresi ulang dapat dilihat pada tabel berikut :

\section{Tabel 8}

Ringkasan Koefisien Jalur Persamaan Struktural III antara Derajat Kesehatan $\left(\mathrm{Y}_{2}\right)$ dengan Tingkat Kemiskinan $\left(\mathrm{Y}_{3}\right)$ setelah Trimming

\begin{tabular}{lllc}
\multicolumn{1}{c}{ Model } & \multicolumn{2}{c}{$\mathbf{Y}_{\mathbf{3}}=\boldsymbol{\rho y}_{\mathbf{3}} \mathbf{y}_{\mathbf{2}} \mathbf{Y}_{\mathbf{2}}+\mathbf{\rho y}_{\mathbf{3}} \mathbf{\varepsilon i}_{\mathbf{4}}$} \\
\hline $\mathrm{R}^{2}$ & 0,742 & \\
\hline $\mathrm{F}$ sig. & $0,000^{\mathrm{b}}$ & \multicolumn{2}{c}{$\begin{array}{l}\text { Coefficients } \\
\text { Beta }\end{array}$} \\
\hline Variabel & \multicolumn{3}{c}{$\mathrm{Prob}}$. \\
\hline $\mathrm{Y}_{2}$ & $\mathrm{Y}_{3}$ & 0,861 & 0,000
\end{tabular}

Sumber: SPSS, 22 Data Diolah, 2021 
Berdasarkan tabel 8 diatas diperoleh nilai koefisien jalur derajat kesehatan $\left(\mathrm{Y}_{2}\right)$ kemiskinan $\left(\mathrm{Y}_{3}\right)$ signifikan, terlihat nilai signifikansi $\mathrm{F}$ dan $\mathrm{t}$ statistik lebih kecil dari 0,05 . Sedangkan nilai residu py3ci4 $=1-0,742=0,258$ sehingga diperoleh persamaan struktural III sebagai berikut:

$$
\begin{gathered}
Y_{3}=\rho y_{3} y_{2} Y_{2}+\rho y_{3} \varepsilon i_{4} \\
Y_{3}=0,861 Y_{2}+0,258 \varepsilon i_{4}
\end{gathered}
$$

Dari persamaan struktural III, dapat dibuat kerangka hubungan kausal antara derajat kesehatan $\left(\mathrm{Y}_{2}\right)$ terhadap tingkat kemiskinan $\left(\mathrm{Y}_{3}\right)$ sebagai berikut:

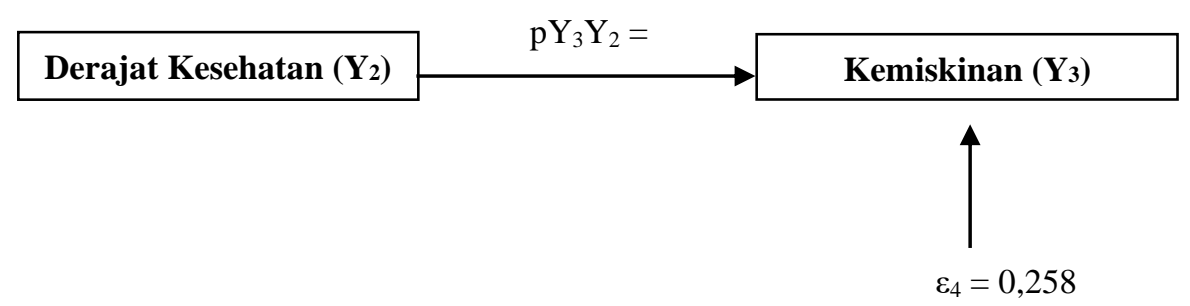

\section{Gambar 7}

Diagram Jalur Persamaan Struktural III antara Derajat Kesehatan dan Tingkat Kemiskinan

Berdasarkan gambar 7 diatas dapat dihitung pengaruh langsung derajat kesehatan $\left(\mathrm{Y}_{2}\right)$ terhadap kemiskinan $\left(\mathrm{Y}_{3}\right)$. Selanjutnya untuk mengetahui berapa besarnya nilai koefisien pengaruh variabel eksogen terhadap variabel endogen secara proporsional adalah sebagai berikut:

Pengaruh langsung derajat kesehatan $\left(\mathrm{Y}_{2}\right)$ terhadap kemiskinan $\left(\mathrm{Y}_{3}\right)$ di kota Jambi

$$
\begin{aligned}
\text { Pengaruh } \mathrm{Y}_{2} \text { terhadap } \mathrm{Y}_{3} & =\left(\rho \mathrm{y}_{3} \mathrm{y}_{2} \mathrm{Y}_{2}\right)^{2} \times 100 \% \\
& =(0,861)^{2} \times 100 \% \\
& =74,2 \%
\end{aligned}
$$

\begin{tabular}{|c|c|c|c|}
\hline \multicolumn{3}{|c|}{ Pengaruh Variabel Derajat Kesehatan $\left(Y_{2}\right)$ Terhadap } & Kemiskinan $\left(\mathbf{Y}_{3}\right)$ \\
\hline Pengaruh & Variabel & $\begin{array}{c}\text { Pengaruh Kausal } \\
\text { Langsung }(\%)\end{array}$ & $\begin{array}{l}\text { Pengaruh Total } \\
(\%)\end{array}$ \\
\hline $\mathrm{Y}_{3} \rightarrow \mathrm{Y}_{3}$ & & 74,2 & 74,2 \\
\hline Pengaruh $\mathrm{I}$ - & Variabel $Y_{2}$ terhadap $Y_{3}=R^{2}$ & & 74,2 \\
\hline Pengaruh $\mathrm{I}$ & Variabel Luar & & 25,8 \\
\hline Total & & & 100 \\
\hline
\end{tabular}

Pengaruh langsung dari variabel eksogen yaitu derajat kesehatan terhadap kemiskinan dapat terlihat pada tabel sebagai berikut:

Tabel 9

Sumber: SPSS, 22 Data Diolah, 2021 
Berdasarkan perhitungan pada tabel 9, menunjukkan bahwa kekuatan derajat kesehatan $\left(\mathrm{Y}_{2}\right)$ yang secara langsung menentukan perubahan-perubahan kemiskinan $\left(\mathrm{Y}_{3}\right)$ sebesar 74,2 persen.

4. Hasil Akhir Skema Path Analysis

Berdasarkan hasil uji dengan 3 persamaan struktural maka dapat ditemaukan hasil akhir diagram jalur yang dapat dilihat pada gamabr berikut :.

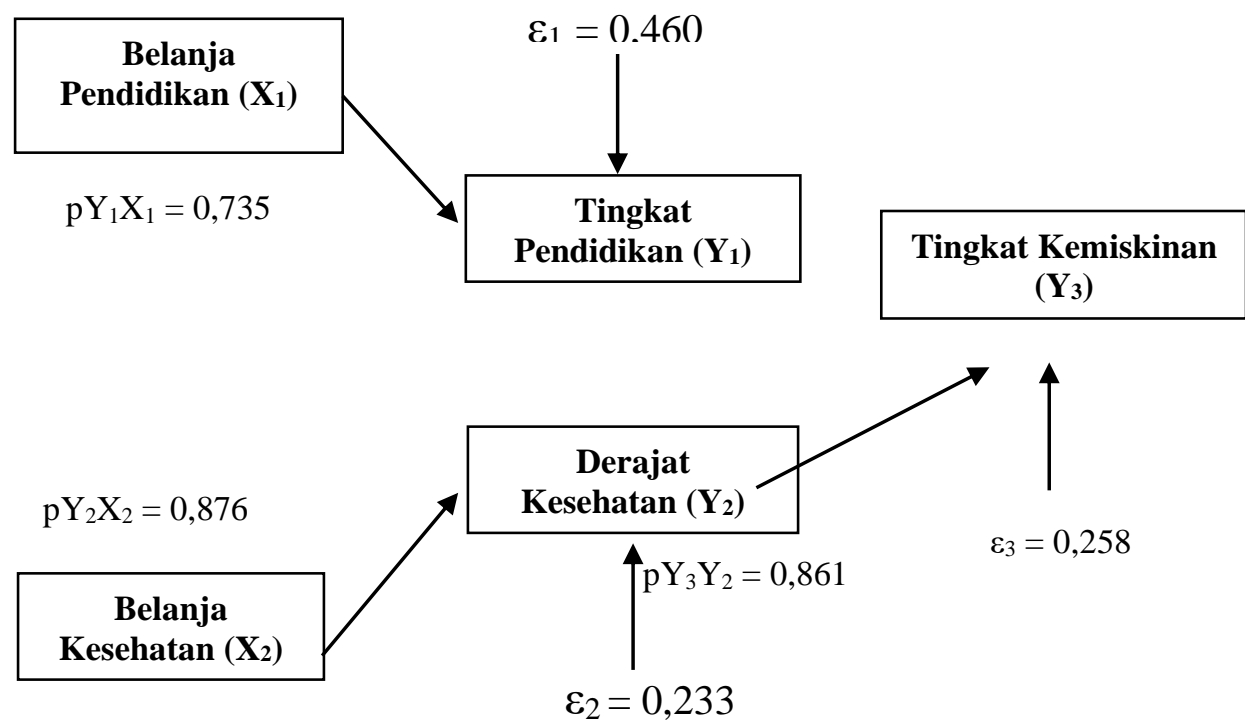

\section{Gambar 8 \\ Diagram Jalur Persamaan Struktural I, Persamaan Struktural II dan Persamaan Struktural III}

\section{Kesimpulan}

Persamaan struktural I menunjukkan bahwa belanja pendidikan berpengaruh signifikan dan positif terhadap tingkat pendidikan, begitu juga belanja kesehatan berpengaruh signfikan dan positif terhadap derajat kesehatan. Pengaruh langsung belanja pendidikan terhadap tingkat pendidikan sebesar 54 persen dan pengaruh langsung belanja kesehatan terhadap derajat kesehatan sebesar 76,7 persen.

Persamaan struktural III menunjukkan bahwa secara parsial hanya variabel derajat kesehatan yang berpengaruh terhadap kemiskinan. Setelah diuji dengan model Trimming, hasil menunjukkan bahwa derajat kesehatan berpengaruh isignifikan dan positif terhadap kemiskinan, sehingga didapat nilai pengaruh langsung derajat kesehatan terhadap kemiskinan sebesar 74,2 persen. 


\section{BIBLIOGRAFI}

Daulay, A. R., Putri, E. I. K., Barus, B., Sumberdaya Lahan, I. P. B., \& Noorachmat, B. P. (2016). Analisis Faktor Penyebab Alih Fungsi Lahan Sawah Menjadi Sawit Di Kabupaten Tanjung Jabung Timur. Google Scholar

Faturahman, F. (2019). Angka Harapan Hidup Sebagai Intervening Anggaran Kesehatan Masyarakat Dan Sumber Daya Manusia Kesehatan Terhadap Kemiskinan Di Kota Jambi. Iltizam Journal Of Shariah Economic Research, 3(1), 24-40. Google Scholar

Hardiani, H., \& Junaidi, J. (2011). Analisis Kuantitas Dan Kualitas Penduduk Sebagai Modal Dasar Dan Orientasi Pembangunan Di Provinsi Jambi. Google Scholar

Harlik, H., Amir, A., \& Hardiani, H. (2013). Faktor-Faktor Yang Mempengaruhi Kemiskinan Dan Pengangguran Di Kota Jambi. Jurnal Perspektif Pembiayaan Dan Pembangunan Daerah, 1(2), 109-120. Google Scholar

Hujaipah, H., Arsa, A., \& Zahara, A. E. (2020). Pengaruh Indeks Pembangunan Manusia (Ipm) Dan Upah Minimum Provinsi (Ump) Terhadap Tingkat Kemiskinan 11 Kabupaten/Kota Di Provinsi Jambi (Tahun 2014-2019). Uin Sulthan Thaha Saifudin Jambi. Google Scholar

Jalaluddin, S., Mubyarto, N., \& Zahara, A. E. (2018). Pengaruh Pertumbuhan Ekonomi, Sumber Daya Manusia, Dan Pengangguran Terhadap Kemiskinan Di Provinsi Jambi Tahun 2010-2016. Uin Sulthan Thaha Saifuddin Jambi. Google Scholar

Jasasila, J. (2020). Analisis Dimensi Pembentuk Indeks Pembangunan Manusia (Ipm) Provinsi Jambi 2010-2019. Ekonomis: Journal Of Economics And Business, 4(2), 389-396. Google Scholar

Mudayana, F. I., \& Suryoko, S. (2016). Pengaruh Kompetensi, Kompensasi, Dan Lingkungan Kerja Terhadap Kinerja Karyawan Melalui Motivasi Kerja Sebagai Variabel Intervening (Studi Kasus Pada Karyawan Bagian Produksi Pt. Sai Apparel Industries Semarang). Jurnal Ilmu Administrasi Bisnis, 5(1), 300-312. Google Scholar

Pake, S. D. S., Kawung, G. M. V, \& Luntungan, A. Y. (2018). Pengaruh Pengeluaran Pemerintah Pada Bidang Pendidikan Dan Kesehatan Terhadap Indeks Pembangunan Manusia Di Kabupaten Halmahera Utara. Jurnal Berkala Ilmiah Efisiensi, 18(4). Google Scholar

Permana, B., Yulmardi, Y., \& Junaidi, J. (2020). Pengaruh Komponen Indeks Pembangunan Manusia (Ipm) Terhadap Pertumbuhan Ekonomi Di Kota Jambi Periode 2004-2018. E-Jurnal Ekonomi Sumberdaya Dan Lingkungan, 9(2), 110122. Google Scholar

Putriani, P., Junaidi, J., \& Edi, J. K. (2018). Pengaruh Pertumbuhan Ekonomi, 
Pendidikan Dan Kesehatan Terhadap Tingkat Kemiskinan Di Kota Jambi Periode 2004-2017. E-Jurnal Ekonomi Sumberdaya Dan Lingkungan, 7(3), 132-143. Google Scholar

Putro, P. B. W., Mintarti, S., \& Wijaya, A. (2018). Analisis Determinasi Pertumbuhan Ekonomi Dan Kemiskinan. Inovasi, 13(2), 121-126. Google Scholar

Rismawati, R. (2018). Pengaruh Jumlah Penduduk, Tingkat Pendidikan, Dan Kesehatan Terhadap Angka Kemiskinan Di Kabupaten Gowa. Universitas Islam Negeri Alauddin Makassar. Google Scholar

Romi, S., \& Umiyati, E. (2018). Pengaruh Pertumbuhan Ekonomi Dan Upah Minimum Terhadap Kemiskinan Di Kota Jambi. E-Jurnal Perspektif Ekonomi Dan Pembangunan Daerah, 7(1), 1-7. Google Scholar

Winarti, A., \& Purwanti, E. Y. (2014). Analisis Pengaruh Pengeluaran Pemerintah Bidang Pendidikan, Kemiskinan, Dan Pdb Terhadap Indeks Pembangunan Manusia Di Indonesia Periode 1992-2012. Fakultas Ekonomika Dan Bisnis. Google Scholar

\section{Copyright holder :}

Eri Nofriza (2021)

First publication right :

Journal Syntax Admiration

This article is licensed under: 